\title{
Circulação e consumo da telenovela Salve Jorge: 0 caso de Maria Vanúbia no Twitter
}

\section{Sandra Depexe}

Doutora em Comunicação, docente do Departamento de Ciências da Comunicação da Universidade Federal de Santa Maria.

E-mail: sandraufsm@yahoo.com.br
Resumo: Com o objetivo de refletir sobre o consumo simultâneo de televisão e do Twitter, o texto articula a análise de discurso peuchetiana com a sociologia bourdiana para captar o funcionamento do imaginário: os modos pelos quais uma personagem é apresentada na telenovela e discursivisada pelo público/audiência no Twitter. Como elemento constitutivo do corpus de pesquisa selecionamos comentários sobre a telenovela Salve Jorge (Rede Globo, 2012/2013), que mencionavam a personagem Maria Vanúbia, papel da atriz Roberta Rodrigues. Como resultado, avaliamos que o sucesso alcançado pela personagem no Twitter é atravessado pela distinção de classe.

Palavras-chave: Recepção/consumo; Circulação; Telenovela; Twitter.

Title: Circulation and consumption of the brazilian telenovela Salve Jorge: the case of Maria Vanúbia on Twitter

Abstract: With the objective of reflecting on the simultaneous use of television and Twitter, the text articulates Pêcheux's discourse analysis with Bourdieu's sociology to capture the workings of the imagination: the ways in which a character appears in the telenovela and as it is commented by the public/audience on Twitter. Selected comments on the telenovela Salve Jorge (Rede Globo 2012/2013) that mention the character Maria Vanúbia, role of actress Roberta Rodrigues, are constitutive elements of the research. As a result, we conclude that the success of the character in Twitter is related with the class distinction.

Keywords: Reception/consumption; Circulation; Telenovela; Twitter. 


\section{Introdução}

${ }^{1}$ Processo que diz respeito ao fluxo de conteúdos através de vários suportes de mídia, à cooperação entre mercados midiáticos e ao comportamento dos sujeitos no consumo de produtos midiáticos e em suas interações sociais (JENKINS, 2009).

${ }^{2}$ Rede social digital onde os usuários podem enviar mensagens (tweets) com até 140 caracteres e fazer o uso de marcadores temáticos (hashtags).

\footnotetext{
${ }^{3}$ As redes sociais digitais se valem substancialmente de recursos discursivos, sejam imagéticos ou textuais.
}

Pensar o atual status do consumo/recepção de telenovelas requer que observemos o ambiente de convergência ${ }^{1}$ em que a mídia televisiva e seus receptores estão imersos. Enquanto Orozco Gómez (2011) alerta para a alteração na relação do espectador com o produto midiático através da expansão das plataformas de distribuição da telenovela para outras telas, Gallego (2013) dá importância ao consumo simultâneo TV-internet e à normalização do uso do Twitter $^{2}$ com o momento de assistência televisiva. No Brasil, alguns trabalhos, dentre os quais citamos Aquino e Puhl (2011); Sifuentes; Vilela e Jeffman (2012) e Oikawa; John e Avancini (2012), apontam para a diversidade de apropriações que os telespectadores fazem das telenovelas nas redes sociais digitais, gerando não apenas conteúdo, mas interações e conversas sobre as tramas nessas redes. Esse panorama é confirmado em uma pesquisa realizada pelo IBOPE Nielsen Online, que indica que $43 \%$ dos internautas brasileiros têm o hábito de ver televisão enquanto utilizam a internet. Desses, $59 \%$ declaram fazer isso todos os dias e $29 \%$ afirmam comentar a programação televisiva nas redes sociais, sendo as telenovelas a temática de maior repercussão (NO BRASIL..., 2012).

Nesse cenário, entendemos que os discursos ${ }^{3}$ presentes nas redes sociais digitais, apesar de geralmente serem pouco desenvolvidos, servem como indícios a respeito dos temas que repercutem - positiva ou negativamente - junto à recepção televisiva. Tanto os conteúdos postados quanto as marcas de interação dos usuários são materializados por discursos, os quais servem como registros de atividades e impulsionam o sentido de um consumo amplificado (OROZCO GÓMEZ, 2011). Logo, defendemos que a pesquisa de recepção/consumo possa ser aliada aos estudos do discurso, para melhor apreender os sentidos elaborados e postos na rede.

Elegemos como objetivo para este texto a reflexão sobre o consumo simultâneo de telenovela e do Twitter para captar o funcionamento do imaginário na superfície: os modos pelos quais uma personagem é apresentada na trama e discursivisada pelo público/audiência na rede social digital. Como elemento constitutivo do corpus de análise, selecionamos comentários sobre a telenovela Salve Jorge (Rede Globo, 2012/2013) que mencionavam a personagem Maria Vanúbia, papel da atriz Roberta Rodrigues.

Assim, este trabalho se caracteriza como um estudo da circulação via Twitter, com foco na recepção da telenovela Salve Jorge. Conjuga as preocupações a respeito do consumo midiático, dos usos e apropriações que os receptores fazem das redes sociais digitais e da narrativa da telenovela. Ou seja, não se trata de apenas compreender como os telespectadores utilizam o Twitter para falar sobre a telenovela, mas como ela é consumida, interpretada e discursivisada nesse espaço.

A seguir, abordamos a circulação e o consumo de telenovela e apresentamos alguns aspectos referentes à circulação de Maria Vanúbia no Twitter, observados durante os sete meses de exibição de Salve Jorge. Em seguida, apresentamos o aporte teórico-analítico onde articulamos a análise de discurso peuchetiana com a sociologia bourdiana para analisar o conteúdo dos comentários sobre a personagem.

\section{Circulação e consumo: televisão e Twitter}

O consumo simultâneo TV-internet implica transformações dos usos e apropriações tanto na assistência televisiva quanto no acesso a uma rede social digital. Por meio do compartilhamento de gostos e opiniões, telespectadores/ internautas constroem outras ritualidades no consumo das duas telas, tornando público não apenas os gostos e as contestações, mas o próprio comportamento 
migratório das audiências (JENKINS, 2009). Entretanto, seria equivocado considerar que somente na cultura da convergência os sujeitos passaram a construir sentidos a respeito daquilo que recebem/consomem dos meios de comunicação. $O$ que difere, agora, é a ampla visibilidade que essas construções alcançam (FAUSTO NETO, 2009; JACKS et al., 2011).

Assim, a cultura da convergência põe em xeque a concepção linear e unidirecional dos fluxos entre produtores e receptores e "origina-se uma espécie de passagem - da produção à recepção - espécie de uma zona que nasce das franjas das fronteiras das dinâmicas entre uma e outro, mas uma zona cujos contornos não são claros [...]" (FAUSTO NETO, 2009, p. 6). Essa zona de passagem a que se refere Fausto Neto (2009) é a circulação, que deixa de ser "invisível" - um conceito abstrato para diferenciar os dois lugares - e passa a ser um dispositivo da heterogeneidade, da redução das distâncias e da articulação entre emissão e recepção.

Compreendemos a circulação da telenovela tanto como o movimento vindo da produção como aquele oriundo da recepção, ou seja, o que a telenovela põe em circulação e o que a recepção, ao consumir, se apropria, (re)elabora e põe também em circulação (no nosso caso, através de comentários no Twitter). A circulação da telenovela, nessa perspectiva, corresponde à exibição da telenovela, e também a todo tipo de produto que se vincule ou se referencie a ela. No âmbito do consumo, a circulação diz respeito às ações dos receptores em produzir conteúdo ou dar visibilidade ao seu próprio consumo midiático, isso é, "trata-se de identificar como os receptores/consumidores relacionam-se com os conteúdos midiáticos, [...] através dos fluxos que emanam ora de um simples redirecionamento que faz expandir a circulação dos conteúdos, ora das apropriações propriamente ditas" (JACKS et al., 2011, p. 301-302).

A circulação, no âmbito do consumo, corresponde às ações e movimentos empreendidos pelos consumidores/receptores de um produto midiático, que apontam tanto para a estabilização quanto para a reformulação de sentidos a respeito de tais produções. Assim, "os comentários feitos no Twitter sobre a telenovela sustentam a hipótese de que a convergência das mídias TV e web potencializam a visibilidade do conteúdo ficcional, além de permitir a construção de novos significados em relação à narrativa" (AQUINO; PUHL, 2011, p. 35).

Pontuamos que grande parte dos estudos que conjugam convergência e telenovela visando a recepção toma como referência a interatividade propiciada pelo emissor, seja em sites oficiais, blogs ou perfis nas redes sociais digitais. Considerando os três volumes da Coleção Teledramaturgia (LOPES, 2009, 2011, 2013), que reúne trabalhos realizados pelos pesquisadores do Obitel Brasil ${ }^{4}$, constatamos que entre os 27 artigos publicados, somente 7 incluíram em suas discussões as atividades dos receptores, sendo apenas 3 artigos - os de Lopes et al., 2009; Jacks et al., 2011 e Jacks et al., 2013 - que abordaram, embora de modo bastante conciso, as ações dos telespectadores desvinculadas de ambientes digitais controlados pela instância emissora da telenovela.

Justamente, nosso interesse de pesquisa está nos lugares que fogem ao controle do emissor midiático, como os comentários realizados pelo público no Twitter que põe a telenovela em um fluxo de livre circulação. Nessa direção, os trabalhos de Aquino e Puhl (2011); Sifuentes; Vilela e Jeffman (2012) e Oikawa; John e Avancini (2012) atentam para as atividades dos receptores nas redes sociais digitais, mas não se dedicam a uma análise que conjugue a narrativa da telenovela e as elaborações dos espectadores em vistas de uma leitura da telenovela. Tomaremos a circulação como lugar que torna visível a ação do receptor para refletir sobre as relações entre a audiência televisiva e a internet, especialmente no Twitter.

${ }^{4}$ O Obitel (Observatório IberoAmericano da Ficção Televisiva) é formado por uma rede de equipes de em 12 países e da região iberoamericana: Argentina, Brasil, Chile, Colômbia, Equador, Espanha, Estados Unidos, México, Peru, Portugal, Venezuela e Uruguai. 


\section{Notas metodológicas e achados empíricos: Maria Vanúbia e o "alerta de recalque"}

A partir de Flick (2009) e Orozco Gómez e González Reyes (2011), optamos pela integração das abordagens de pesquisa quantitativa e qualitativa. $O$ viés quantitativo corresponde aos métodos e técnicas de coleta de dados, onde utilizamos ferramentas de monitoramento e análise de redes sociais digitais, tendo como inspiração Lopes e Freire (2012) e Monteiro e Azarite (2012). Já o viés qualitativo diz respeito às temáticas que selecionamos para análise, que são iluminadas pela análise de discurso para compreender a construção de sentidos pelos receptores sobre a personagem Maria Vanúbia da telenovela Salve Jorge, no que tange a um certo estilo de vida.

Frequentemente, no âmbito das redes sociais digitais, são supervalorizados os dados quantitativos em detrimento dos qualitativos. No campo do monitoramento dessas mídias, em geral, os números - de usuários, acessos, assinantes, seguidores ou comentários - são postos como indicadores de sucesso de uma página ou tema; porém, essas métricas devem ser questionadas em virtude do conteúdo a que se referem, como apontam Monteiro e Azarite (2012). Cabe lembrar que os assuntos polêmicos e as manifestações contrárias a um tema também geram repercussão em termos quantitativos, sendo preciso estar em alerta sobre o que os números de um suposto sucesso podem ocultar.

Lopes e Freire (2012) propõem uma reflexão crítica sobre as ferramentas utilizadas na análise de redes sociais e sua aplicação nos estudos de recepção, particularmente no que se refere ao monitoramento online da audiência televisiva. Concordamos com as autoras sobre a necessidade de questionar as escolhas metodológicas que o uso de tais ferramentas impõe à pesquisa, pois "é ingênuo pensar que os relatórios automáticos não trazem consigo a problemática epistemológica da observação e percepção do objeto estudado" (LOPES; FREIRE, 2012, p. 16). Isso é, os gráficos precisam ser interpretados e não meramente aceitos como um retrato generalista da atividade da recepção.

Para Gallego (2013), as métricas quantitativas são responsáveis por uma noção da extensão e do impacto que as redes sociais geram, mas são as métricas qualitativas as que revelam o interesse que os usuários/consumidores têm sobre um tema em específico. Compreendemos que o monitoramento das atividades no Twitter, além de servir como métrica sobre quais assuntos ganham destaque socialmente, pode revelar preferências que os dados quantitativos sobre as audiências televisivas ocultam. Assim, "Twitter é um eletrocardiograma da sociedade e, dentro dela, é uma plataforma que mede muito bem o pulso do que

5 "Twitter es un electrocardiograma de la sociedad y, dentro de ella, es una plataforma que toma bien el pulso a lo estrictamente televisivo" (GALLEGO, 2013, p. 15). se refere exclusivamente à televisão"5 (GALLEGO, 2013, p. 15, tradução minha).

Durante a exibição de Salve Jorge, monitoramos, sempre ao final dos capítulos, a atividade no Twitter referente à telenovela. Dedicamos-nos ao acompanhamento da listagem dos trend topics, isso é, a listagem dos dez termos mais citados na rede, e também monitoramos sistematicamente os comentários que a audiência realizava com o marcador "\#salvejorge". Entre 22 de outubro de 2012 (data da estreia da telenovela) e 17 de maio de 2013 (último capítulo), foram capturados 34.160 comentários sobre a personagem Maria Vanúbia no Twitter, através da ferramenta NCapture do software NVivo 10.

Inicialmente, com auxílio do NVivo 10, criamos a nuvem de palavras (Figura 1) dos termos mais frequentes nessa base de 34.160 tweets coletados. A partir dela traçamos algumas observações que nos permite lançar um primeiro olhar para "o que se diz" sobre a personagem Maria Vanúbia no Twitter. 


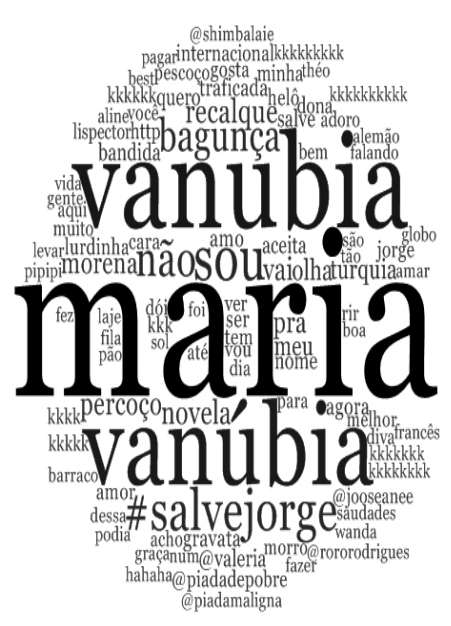

Figura 1: Nuvem de palavras para os comentários sobre Maria Vanúbia.

Fonte: Imagem obtida por manipulação dos dados no NVivo 10, com base em 34.160 tweets.

Maria Vanúbia, personagem interpretada por Roberta Rodrigues, faz parte do núcleo ambientado no Complexo do Alemão, lugar onde vive a protagonista Morena (Nanda Costa). Desde o início da trama a relação entre as duas é tensa, sendo comuns as cenas de provocação verbal e até mesmo agressão física entre elas. Maria Vanúbia, entretanto, é uma personagem secundária e contracena, majoritariamente, com outros personagens do núcleo, mantendo-se quase restrita a ele.

A filiação de Maria Vanúbia à classe popular é reforçada pelo uso extremamente coloquial da linguagem, o que alude a um baixo capital cultural escolar (BOURDIEU, 2011). Além de pronunciar de forma errônea algumas palavras, incluindo o apelido de seu flerte "Percoço" (trocando o "s" por " $r$ "), todos os atos de fala da personagem são marcados por bordões, por exemplo: "Eu sou Maria Vanúbia, não sou bagunça", "Aceita que dói menos", "Quem é você na fila do pão francês?", "Tô no salto, no brilho, no gloss", "Eu morro de rir, mas não acho graça", "Pipipi, olha o recalque", "Pipipi, alerta de recalque", os quais ganharam a simpatia do público e eram automaticamente replicados no Twitter em todas as cenas em que eram proferidos, como pudemos observar em nosso monitoramento e na base de tweets coletados. O uso dessas expressões, de certo modo, pontua o dizer da personagem e remete às observações feitas por Hoggart (1973) de que as classes populares, em geral, expressam suas "opiniões" por meio de um amontoado de frases feitas e transmitidas pela tradição oral.

A nuvem de palavras é indiciária da apropriação dos bordões de Maria Vanúbia pelo receptor. Em dados quantitativos, as palavras-chave desses bordões são encontradas repetidamente: "bagunça" foi citada 4.459 vezes; "recalque" foi mencionada em 2.616 ocasiões; "francês" foi referenciada 385 vezes e "percoço" aparece em 2.408 ocasiões. Como forma de ilustrar essas menções, reproduzimos alguns tweets ${ }^{6}$ coletados.

${ }^{6}$ Optamos por manter a grafia original dos tweets, incluindo erros de escrita, abreviações, sinais gráficos, gírias e onomatopeias para o riso. Também mantemos em anonimato a origem ou autoria dos comentários.
"Sou maria vanubia, $\mathrm{n}$ sou bagunça" citação favorita! \#SalveJorge hahahahahaha (08 mar. 2013)

Quem e você na fila do pão francês? Kkkkkkkkkkkkkkkkkkkkkkkkkkkkkkk essa Maria Vanubia é uma piada!!! \#SalveJorge (13 mar. 2013)

Aceita que dói menos! Kkkkk Maria vanubia e percoço a melhor parte da novela \#salvejorge (12 abr. 2013)

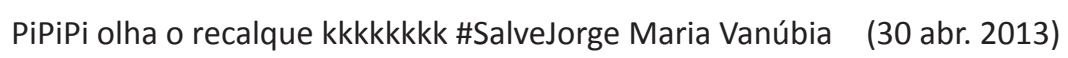

Pipipipipi, eu tô no salto, no brilho e no gloss. Sou Maria Vanúbia e não sou bagunça!! KKKKKKKKKKKKKKKK AMO ELA! (10 maio 2013)

Cabô pipipi, cabô "sou maria vanúbia e eu não sou bagunça", cabô recalque internacional, cabô "escuta aqui deuzuitixxx" cabô tudo): (17 maio 2013) 
${ }^{7}$ Dados obtidos através de observação sistemática da listagem dos trend topics nos dias: 27 de fevereiro de 2012; 19 e 21 de março de $2013 ; 5,12,22,27$ e 30 de abril de 2013; 10, 11 e 13 de maio de 2013.

${ }^{8}$ Disponível em: <http://trendsmap. com/>. Acesso em: 28 jul. 2015.

Discutimos sobre o uso dessa
As séries de "kkkk" e demais onomatopeias para o riso nos chamam a atenção tanto na nuvem de palavras quanto no exame dos tweets coletados. Essas sequências de caracteres remetem ao conceito de corpografia (DIAS, 2008): a textualização da presença/emoção do receptor, que também é virtualizada pelo uso de sinais gráficos que expressam sentimentos de afetividade ou tristeza. Dessa forma, "o que define particularmente a corpografia é que ela não representa nem imita uma emoção, mas ela cria essa emoção, nas condições de produção muito específicas do uso do computador" (DIAS, 2008, p. 20). O registro dessas emoções nos fazem crer na aceitação da personagem e, por que não dizer, no surgimento de fãs de Maria Vanúbia? Afinal, "é a partir do momento em que o telespectador passa a se envolver emocionalmente com a trama e a criar laços profundos com a ficção, que se pode considerar que ele se tornou um fã" (LOPES et al., 2013, p. 140).

O nome "Maria Vanúbia" figurou entre os termos mais citados no Twitter em dez datas ${ }^{7}$ diferentes, tendo atingido seu ápice em 13 de maio de 2013, onde verificamos quatro trends que faziam alusão à personagem: "Maria Vanúbia e Morena", "Maria Vanubia", "\#MariaVanubia" e "Recalque". O capítulo exibido nessa data foi marcado por cenas de ação protagonizadas por Maria Vanúbia e Morena contra a quadrilha que as traficou. Em um ambiente protegido pela polícia, ambas celebram as pazes e relembram o passado de discórdia. A conversa vai tomando ares de discussão quando Maria Vanúbia, finalmente, profere seu bordão, atualizando-o para o contexto da cena: "pipipi, agora o recalque é internacional". Como resultado, a observação sistemática dos tweets que utilizavam o marcador "\#salvejorge" demonstrou que os receptores estavam replicando a frase, comentando as cenas, elogiando e declarando seu "amor" à personagem. Para ter a dimensão do que a fala de Maria Vanúbia representava nesse episódio, recorremos à ferramenta Trendsmap ${ }^{8}$, que fornece a localização geográfica e apresenta graficamente o volume de menções a uma palavra no Twitter. Obtivemos a comprovação de que Vanúbia estava certa: "recalque" atingiu presença internacional, como mostra a Figura 2.

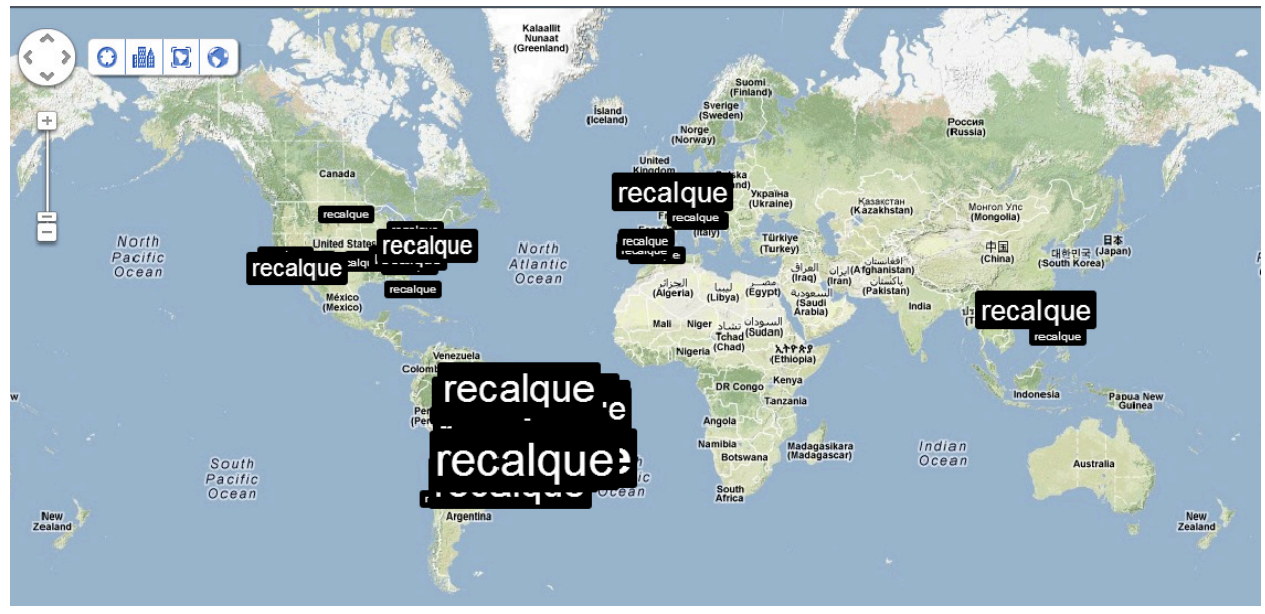

Figura 2: Recalque no mundo.

Fonte: Imagem coletada no Trendsmap em 13 de maio de 2013 às 22h50min.

Através da ferramenta ReSearch.ly ${ }^{9}$, recuperamos a informação quantitativa de 83.070 tweets que mencionavam "recalque" na mesma data. Embora a palavra seja de uso comum, e portanto nem todos os tweets contabilizados por essas ferramentas digam respeito à expressão de Maria Vanúbia, a comparação do volume de menções nos diferentes meses não deixa dúvidas do poder e da visibilidade que a telenovela tem no Twitter, como mostra o gráfico da Figura 3. Da mesma forma, atesta o consumo simultâneo TV-internet e indicia o envolvimento do receptor com a trama. ferramenta em Depexe (2013).

${ }^{9}$ Disponível em: <http://

rs.peoplebrowsr.com/>. Acesso em: 28 jul. 2015. Discutimos sobre o uso dessa ferramenta em Depexe (2013). 


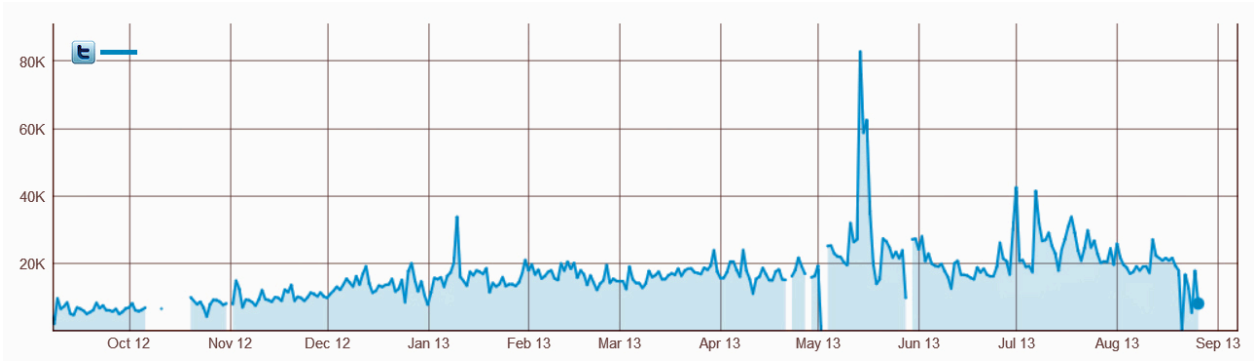

Figura 3: Volume de menções para "recalque".

Fonte: Imagem coletada no ReSearch.ly em 26 de agosto de 2013 às 19h12min.

Considerando o volume de dados que coletamos e a própria trajetória da telenovela, podemos afirmar que existe relação entre a presença de Maria Vanúbia nos comentários no Twitter e seu aumento de importância na trama. Ousamos levantar a hipótese de que seu êxito junto aos receptores contribuiu para que a autora da trama, Glória Perez, incluísse a personagem no início do desfecho da problemática principal de Salve Jorge: o tráfico de pessoas. Em todo caso, a observação que realizamos no Twitter mostra que a convergência midiática e sua cultura é viva: atesta o consumo da rede social digital em tempo real à exibição de Salve Jorge. A seguir, nos dedicamos ao exame qualitativo do conteúdo dos comentários coletados na rede social digital a respeito de Maria Vanúbia.

\section{Notas teórico-analíticas: dispositivo de análise}

Nossa leitura acerca dos comentários realizados pela audiência da telenovela no Twitter remete à análise das condições de produção do discurso, que dizem respeito aos sujeitos implicados e a situação - entendida como exterioridade linguística -, de modo que correspondam a certo lugar no interior de uma formação social dada.

As condições de produção do discurso são explicadas por Pêcheux (2010) através das relações de força, das relações de sentido e do mecanismo de antecipação. As relações de força são exteriores à situação do discurso e instituem que "a mesma declaração pode ser uma arma temível ou uma comédia ridícula segundo a posição do orador e do que ele representa, em relação ao que diz" (Ibid., 2010, p. 76). As relações de sentido que se manifestam na situação discursiva alertam para as relações entre os discursos, isso é, que "o discurso se conjuga sempre sobre um discurso prévio" (Ibid., p. 76). Já o mecanismo de antecipação "implica que o orador experimente de certa maneira o lugar de ouvinte a partir de seu próprio lugar de orador" (Ibid., p. 76), ou seja, essa antecipação do que o outro vai pensar revela a capacidade do sujeito de articular seu discurso buscando produzir determinados efeitos em seu interlocutor.

Esses três elementos - relações de força, relações de sentido, antecipação - são regulados pelas formações imaginárias. Para Pêcheux (2010, p. 81-82),

o que funciona nos processos discursivos é uma série de formações imaginárias que designam o lugar que $A$ e $B$ se atribuem cada um a si e ao outro, a imagem que eles se fazem de seu próprio lugar e do lugar do outro. Se assim ocorre, existem nos mecanismos de qualquer formação social regras de projeção, que estabelecem as relações entre as situações (objetivamente definíveis) e as posições (representações dessas situações).

Dessa forma, o que funciona no discurso são as imagens dos sujeitos, isso é, as posições discursivas produzidas pelas formações imaginárias, e não os sujeitos empíricos em si. As formações imaginárias se referem ao ponto de vista do sujeito enunciador em relação ao seu interlocutor e também ao referente (contexto ou 
${ }^{10}$ Para Bourdieu (1996), o espaço social organiza-se com base em três dimensões: o volume global do capital possuído pelos sujeitos; a estrutura do capital de acordo com o peso relativo do capital econômico; e do capital cultural no conjunto do patrimônio - evolução no tempo, do volume e estrutura do capital.

${ }^{11}$ Trata-se de "reconhecer a telenovela como componente de políticas de comunicação/cultura que perseguem o desenvolvimento da cidadania e dos direitos humanos na sociedade" (LOPES, 2009, p. 32). situação). Logo, o ponto de vista do receptor/internauta em relação à personagem Maria Vanúbia na telenovela Salve Jorge não escapa do embate entre aquilo que o receptor "espera" da personagem e a posição que essa personagem assume na trama. Neste trabalho, consideramos que as formações imaginárias são vinculadas às representações da mulher e ao modo como os receptores consomem e se apropriam das narrativas teledramaturgas.

Tomamos aporte dos conceitos de habitus, estilo de vida e dos capitais propostos por Pierre Bourdieu para pensar as práticas que distinguem as classes sociais e que permitem filiar as personagens da telenovela a uma certa realidade social para ser interpretada pelo receptor. Bourdieu (2011) metaforiza o conceito de capital, central na teoria marxista, em quatro dimensões: econômica, cultural, social e simbólica. O capital econômico inclui riqueza, renda, heranças financeiras e ativos monetários. O capital cultural pode ser pensado sob três formas: estado corporificado (disposições da mente e do corpo), estado objetivado (bens culturais) e estado institucionalizado (qualificações educacionais). O capital social se refere à posição ocupada nas relações sociais e, por fim, o capital simbólico diz respeito ao poder simbólico, ao que dá sentido e legitimidade aos demais capitais.

Embora os quatro capitais propostos por Bourdieu sejam úteis para o exame das classes, Skeggs (2002) alerta que a metáfora não deve ser compreendida como descrições de posições empíricas. As classes sociais pensadas por Bourdieu se referem às correspondências entre o espaço de posições ocupadas no espaço social $^{10}$ e o espaço de disposições: o habitus, a unidade de estilo que vincula práticas e bens de um sujeito ou de uma classe (BOURDIEU, 1996). Consideramos que o estilo de vida é produto do habitus e exprime na lógica simbólica uma certa preferência distintiva de classe a ser lida na mobília, na vestimenta, na linguagem e na hexis corporal (Id., 1983).

Em nosso dispositivo de análise (Figura 4), sugerimos que o habitus, os capitais e o estilo de vida funcionam como instâncias vinculadas às formações imaginárias, visto que "o habitus implica não apenas um sense of one's place, mas também um sense of other's place" (Id., 2004, p. 158, grifos do autor). Cabe ressaltarmos que para Lopes (2009), a telenovela, como "recurso comunicativo11", ativa a correspondência entre o habitus do mundo narrado e o habitus vivido pela recepção, possibilitando o reconhecimento de si e do outro. Esse senso de posições de sujeito, quando examinados à luz das narrativas ficcionais, traz à tona a construção das personagens, os sentidos em oferta ao receptor televisivo e as apropriações realizadas no âmbito do consumo simultâneo no Twitter.

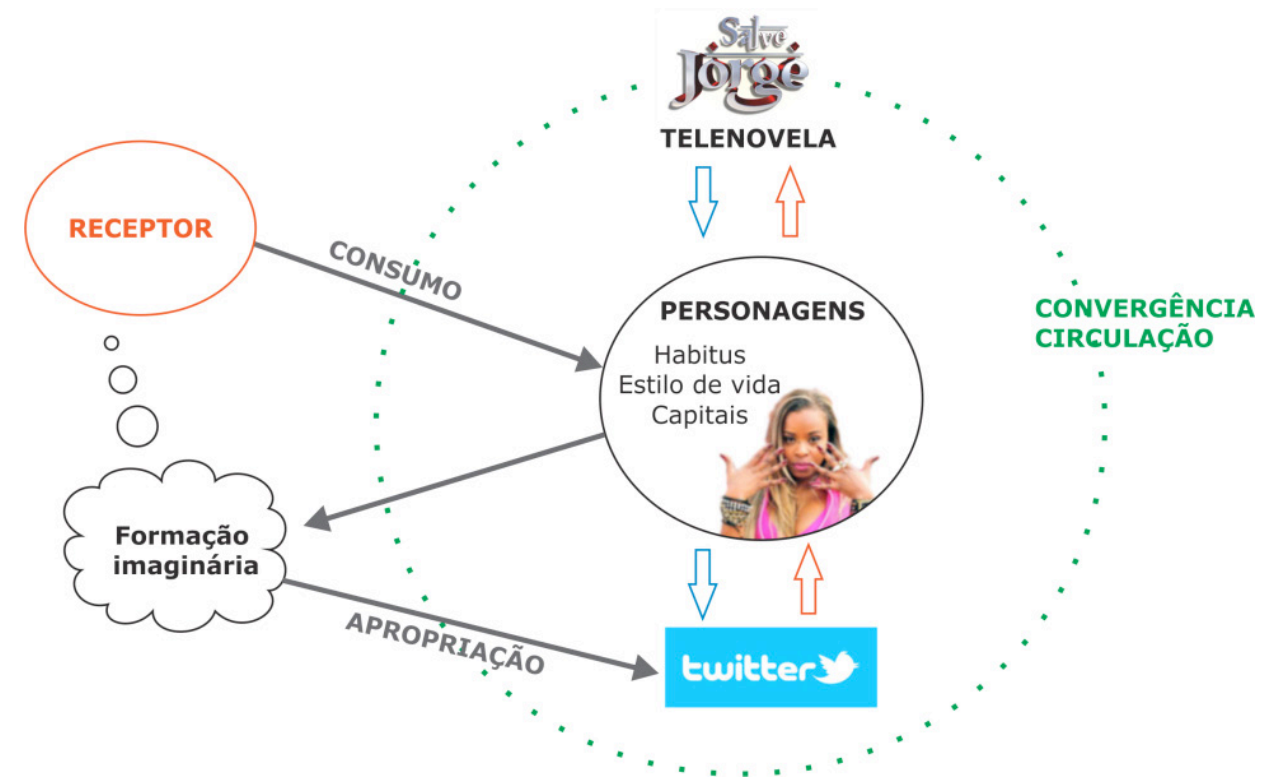

Figura 4 - Dispositivo de análise

Fonte: A autora. 
Os comentários no Twitter, em nosso entendimento, materializam as leituras que os receptores fazem da telenovela e também a presença do receptor nas redes sociais digitais. Assim, é pela escrita (pelo comentário postado) que a recepção se torna visível e faz funcionar a cultura da convergência, pondo em circulação não apenas imaginários, mas a própria audiência televisiva.

Nas análises a seguir buscamos conjugar a circulação e o consumo da telenovela Salve Jorge, especificamente da personagem Maria Vanúbia, em um mesmo gesto metodológico de leitura, descrição e interpretação.

\section{Maria Vanúbia: estilo de vida e classe}

12 “Periguete do Alemão, é cheia de si e não deixa barato nenhuma provocação. Está sempre flertando com Pescoço e provocando Delzuite". Disponível em: $<$ http://tvg.globo.com/novelas/ salvejorge>. Acesso em: 10 maio 2013.

${ }^{13}$ Cardoso (2012) rememora quem foram as primeiras periguetes nas telenovelas da Rede Globo: Natalie (Deborah Secco) em Insensato Coração (2011), Teodora (Carolina Dieckmann) em Fina Estampa (2011/2012) e Suelen (Ísis Valverde) em Avenida Brasil (2012). ${ }^{14}$ Conforme Chanter (2011, p. 36), o mito da hipersexualidade constrói a sexualidade das mulheres negras como imoral, patológica e incontrolável, em oposição às mulheres brancas tidas como puras, sem paixão e assexuadas.

${ }^{15} \mathrm{Na}$ gíria utilizada pelo receptor,

"mostrar o capô de fusca" alude a uma imaginária semelhança entre o capô do automóvel e o formato que o biquíni dá à região pubiana feminina.
A descrição da personagem Maria Vanúbia no site oficial de Salve Jorge ${ }^{12}$ é marcada por um imaginário que alude à violência da periferia, aponta para uma personalidade forte, "cheia de si", e reforça sentidos já dados às periguetes ${ }^{13}$ das telenovelas: pertencimento à classe popular e ameaça ao casamento. No caso da personagem, a nomeação de periguete e o par raça-classe corrobora o imaginário analisado por Nascimento e Alves (2011), que denigre as mulheres negras e mestiças de classe popular em prol do mito da hipersexualidade ${ }^{14}$. Os receptores, entretanto, elaboram suas interpretações pela comparação das trajetórias dessas personagens periguetes.

Os comentários indicam embates entre a posição imaginária de uma mulher liberal, vinda pela recordação de Suelen (Ísis Valverde em Avenida Brasil) e pelas atitudes de Maria Vanúbia. Enquanto aquela firmou relacionamento concomitante com dois homens, essa fica de biquíni na laje ${ }^{15}$ e não protagoniza cenas que sinalizem envolvimento sexual com diferentes parceiros ao longo da telenovela. Alguns receptores questionam se ela seria mesmo periguete, afinal, quem se envolve em um caso de infidelidade é Dona Isaurinha (Nívea Maria), e até mesmo os personagens masculinos Zyah (Domingos Montagner) e Théo (Rodrigo Lombardi) tiveram mais parceiras sexuais que ela, como indica as amostras de comentários capturados no Twitter:

Piriguete de Avenida Brasil: Suellen, casa com dois homens. Piriguete de \#SalveJorge: Vanúbia, mostrar o capô de fusca na laje. (5 mar. 2013)

O Théo é mais piriguete que a Lurdinha e a Maria Vanúbia juntas. \#SalveJorge. (8 abr. 2013)

Zyah já pegou duas mulheres, theo já pegou quatro...depois a perigueti é a Maria Vanúbia \#salvejorge. (11 abr. 2013)

Chamam Maria Vanúbia de piriguete, mas quem traiu a melhor amiga foi a \#Donalsaurinha \#salvejorge. (66' kkkkkkk. (17 maio 2013)

Embora Maria Vanúbia mantivesse, até certo ponto, um comportamento sexual mais conservador que o de Suelen, fazendo cair por terra o mito da hipersexualidade da mulher negra de origem popular, o imaginário de que a periguete é uma mulher perigosa, provocante (CERQUEIRA; CORRÊA; ROSA, 2012) é mantido uma vez que a personagem flerta com Pescoço (que vive com Delzuite) e faz gracejos para Clóvis (Walter Breda), dono de bar e esposo de Diva (Neusa Borges), que a espia, com um binóculo, tomar banho de sol.

O estilo de vida (BOURDIEU, 1983) de Maria Vanúbia remete aqueles associados às periguetes através da valorização do corpo feminino, dos cuidados estéticos e da diversão. Conforme apontam Soares (2012) e Nascimento e Alves (2011), as roupas, o cabelo, a autoestima elevada e a forma de lidar com o corpo correspondem a elementos distintivos e representacionais das periguetes. $\mathrm{Na}$ 
Figura 5, apresentamos o estilo de Maria Vanúbia, que é similar à imagem corporal da periguete já instituída por outras personagens de telenovelas da Rede Globo.

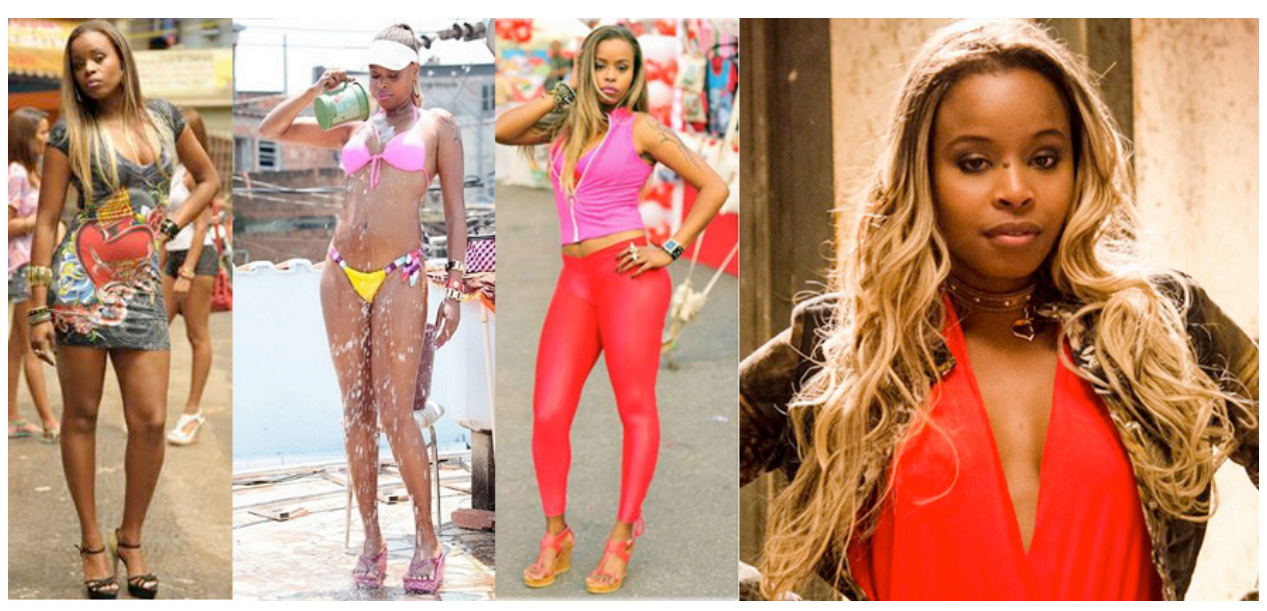

Figura 5: O estilo de Maria Vanúbia

Fonte: Montagem realizada pela autora, com imagens retiradas do site da Rede Globo.

Assim, além das roupas justas e decotadas, são recorrentes as cenas onde Maria Vanúbia aparece de biquíni tomando banho de sol na laje, momento em que utiliza métodos caseiros para "dourar" os pelos do corpo ou para assegurar o bronzeado. A crítica do público em relação às disposições representadas pela personagem e a assistência da telenovela, como ritual frequente, é confirmada nos tweets que aludem ao acompanhamento da narrativa.

Vontade de pagar uma depilação a laser pra essa Maria Vanubia, pra ela parar de loirar os pêlos na laje. (19 mar. 2013)

Não sei como essa maria vanubia ainda não pegou um cançer de pele, pq todo santo dia ela ta se bronzeando nessa laje. (28 mar. 2013)

Essa Maria Vanubia é uma vagabunda msm, só fica pegando sol! Vai arranjar um trabalho, minha filha! (9 abr. 2013)

Olha, Maria Vanúbia fazendo o que todo pobre adora. Pegando sol na laje, com o boné na cabeça e tomando um suco de goiaba. \#SalveJorge (9 abr. 2013)

Ainda, em relação à aparência, as pulseiras, as unhas compridas e pintadas, o mega hair de longos cabelos loiros e lisos em contraste com sua pele negra, faz escapar a ideologia de uma estética hegemônica - branca e loira. Embora negue sua raça pela mudança no cabelo, valoriza, justamente, a cor de sua pele. Porém, fica nítido nos tweets que beleza é uma categoria considerada não pertencente à Maria Vanúbia. Isso remete aos apontamentos de Lipovetsky (1997), onde a valorização do belo está associada à divisão social das classes, de modo que as mulheres pertencentes às classes elevadas isentas do trabalho poderiam dedicar o tempo ocioso aos cuidados pessoais. Logo, "a cultura do belo sexo exigiu a desigualdade social, o luxo e o desprezo do trabalho produtivo por parte das leisured classes" (Ibid., p. 104). Por vezes, a rejeição à imagem corporal da personagem se contrapõe a outras características admiradas pela audiência.

É feia, encorpada, periguete, a encarnação de tudo que eu prego contra... Mas amo de paixão Maria Vanúbia! \#SalveJorge (28 jan. 2013) 
uma pessoa que acha a maria vanubia bonita nunca vai ter credito de nd na vida. (22 mar. 2013)

Gente aquela MARIA VANUBIA é tão feia né? eu acho ela engraçada, mas é bem feinha kkk. (9 abr. 2013)

Maria Vanúbia é feia só de rosto, eu acho o corpo dela bonito apenas.... (12 abr. 2013)

Apesar da aparência de Maria Vanúbia não agradar, ela é aceita pelo público como periguete, mas convém observar que se trata de uma periguete com "personalidade forte", "boa pessoa" - como se esses atributos não correspondessem às demais periguetes, que estariam vinculadas a um imaginário de futilidade e falta de caráter. Vale lembrar que Natalie, Teodora e Suelen, citadas por Cardoso (2012), faziam de seus corpos moeda de troca para adquirir vantagens e conquistar um marido rico, enquanto Vanúbia se divertia ao provocar os homens e dizia querer "subir na vida" por méritos próprios, sem precisar depender de um casamento. Implicitamente funciona a distinção entre "ser" e "parecer" periguete. Nesse aspecto, a personagem se veste como periguete, mas não necessariamente merece a alcunha por suas atitudes.

MARIA VANÚBIA É A PIRIGUETE MAIS ENGRAÇADA DE TODAS HAHAHAHAHAHAHAHAHAHAHAHAHAHA!!! \#SalveJorge (1 fev. 2013)

A Maria Vanúbia é apenas periguete mas é boa pessoa. (14 mar. 2013)

Maria Vanubia a periguete mais 'arretada' de \#SalveJorge (15 mar. 2013)

Hoje a Vanúbia não apareceu ainda. PALHAÇADA! AMO AQUELA PIRIGUETE! \#SalveJorge (25 mar. 2013)

Maria Vanubia melhor piriguete que já vi kkkkk \#SalveJorge (10 maio 2013)

Rsrsrs Vanúbia arrasa. Faz um tipo piriguete de muito personalidade. \#salvejorge (15 maio 2013)

Em termos de capital social (BOURDIEU, 2011), isso é, a posição ocupada nas relações sociais, avaliamos que Maria Vanúbia é conhecida por todos no Complexo do Alemão, mantendo-se praticamente restrita a esse núcleo da telenovela. Assim, suas relações sociais são desenvolvidas no contexto estrito de uma localidade específica, em tom semelhante ao que Hoggart (1973) observou sobre o bairro como lugar de apego para as classes proletárias. Cabe ressaltar que não há representação de Maria Vanúbia como mulher pertencente à esfera privada, do lar. Pelo contrário, o lugar ocupado por ela é pautado pelo espaço público, uma vez que está na rua ou na laje, ambiente a priori privado, mas que se torna público pela presença constante de olhares de homens e dos assovios e cantadas de Pescoço.

Durante o período de exibição da telenovela, poucas vezes se mencionou a ocupação da personagem (dançarina de funk), o que reforça o imaginário de um lugar social menos privilegiado. Maria Vanúbia mantém seus esforços unicamente em sua aparência por acreditar que seu talento para a dança a tornará rica e famosa. Logo, a personagem é construída discursivamente como alguém que busca ascensão social, mas não se dedica ao trabalho ou ao estudo, aspectos geralmente atribuídos às classes mais elevadas. $O$ imaginário sobre os hábitos das classes populares é reforçado pelo gosto musical (funk, samba e pagode) e pelos lugares que frequenta: o bar de Clóvis e Diva, a Estudantina Musical e o Pagofunk. Nos termos de Bourdieu (2011), a personagem possui baixo capital econômico e cultural, posição que a filia às classes populares. 
A partir de nosso dispositivo de análise, podemos aferir que aformação imaginária (PÊCHEUX, 2010) prioritária onde se inscreve Maria Vanúbia é conjugada por sua condição econômica, pelo lugar onde vive (Complexo do Alemão), pelo seu estilo de vida e sua raça. Maria Vanúbia é o oposto da estética dominante; é briguenta, fala errado, mas possui como valor positivo uma grande autoestima, que é trabalhada pela atriz Roberta Rodrigues com um toque bem-humorado. 0 imaginário da periguete como uma mulher que foge à moral tradicional escapa, uma vez que a personagem não aparece em cenas de sexo, nem se envolve com outros personagens, mantendo-se na esfera do flerte com Pescoço.

\section{Considerações finais}

Os comentários no Twitter materializam a presença dos sujeitos, constituindo o sentido de rede social. No caso da telenovela, o uso de marcadores específicos como "\#salvejorge" permite que os temas e emoções publicizados sejam vinculados uns aos outros, legitimando as elaborações e imaginários da recepção em uma instância não controlada pela produção/emissão da telenovela e acessível a todos que compartilham do mesmo código de escrita na rede.

Como resultado, apontamos que embora a personagem Maria Vanúbia seja secundária na trama de Salve Jorge, alcançou grande visibilidade no Twitter. Ao final da novela, Maria Vanúbia é vítima de tráfico humano, onde se tornaria prostituta na Turquia. Entretanto, ela não aceita essa posição e age para fugir da situação que lhe é imposta. O imaginário de que a mulher que vive no morro é preparada para lidar com a violência e é violenta se for preciso é mais uma vez acionado. A periguete, enfim, mostra que é "do bem" e se torna heroína, ao lado da protagonista Morena.

Os comentários na rede social digital explicitam aceitação do público à personagem e indiciam o consumo simultâneo das mídias. Chama-nos atenção que palavras pertencentes aos bordões de Maria Vanúbia entram para os trend topics instantes depois de transmitidas pela televisão. "Recalque", na listagem dos termos mais citados do Twitter, ao final de um dos capítulos onde há uma atualização do já famoso "pipipi, alerta de recalque", atesta não só o consumo simultâneo das mídias, mas o envolvimento do receptor com a trama e com a personagem, revelando outras ritualidades na assistência televisiva.

No que tange à representação do feminino, há designação de Maria Vanúbia como periguete na telenovela; entretanto, os próprios receptores, por vezes, constroem outros sentidos sobre a personagem, afastando-a do imaginário negativo que a alcunha de periguete Ihe impõe. Entretanto, a oposição às suas disposições de classe popular, entre elas à sua estética, revela o funcionamento da distinção de classe sob os olhos da recepção. Em outras palavras, parecenos que é aceita a matriz do riso e da comicidade, mas a classe popular ainda é rechaçada no que diz respeito à sua aparência e seu estilo de vida.

\section{Referências Bibliográficas}

AQUINO, M. C.; PUHL, P. Vale tudo no Twitter: a visibilidade da ficção televisiva em tempos de convergência midiática. Alceu, v. 12, n. 23, p. 34-48, jul./dez. 2011.

BOURDIEU, P. Gostos de classe e estilos de vida. In: ORTIZ, R. (Org.). Pierre Bourdieu: sociologia. São Paulo: Ática, 1983. p. 82-121.

. Razões práticas: sobre a teoria da ação. Campinas: Papirus, 1996.

. Coisas ditas. São Paulo: Brasiliense, 2004. 
. A distinção: crítica social do julgamento. 2. ed. Porto Alegre: Zouk, 2011.

CARDOSO, E. de A. O 'ete' da empreguete. Revista Língua Portuguesa, ano 8, n. 81, p. 16-17, jul. 2012.

CERQUEIRA, L. C. de; CORRÊA, L. G.; ROSA, M. G. A cartilha da mulher adequada: ser piriguete e ser feminina no Esquadrão da Moda. Revista Contracampo, Niterói, v. 24, n. 1, p. 120-139, jul. 2012.

CHANTER, T. Gênero: conceitos-chave em filosofia. Porto Alegre: Artmed, 2011.

DEPEXE, S. Monitoramento online, televisão e Twitter: apontamentos para a pesquisa de recepção. In: V SEMINÁRIO INTERNACIONAL DE PESQUISA EM COMUNICAÇÃO. Anais... Santa Maria, 2013.

DIAS, C. Da corpografia: ensaio sobre a língua/escrita na materialidade digital. Santa Maria: PPGL, 2008.

FAUSTO NETO, A. Olhares sobre a recepção através das bordas da circulação. In: XVIII ENCONTRO DA COMPÓS, 2009, Belo Horizonte. Anais... Disponível em: <http:// www.compos.org.br/data/biblioteca_1164.pdf>. Acesso em: 25 ago. 2013.

FLICK, U. Introdução à pesquisa qualitativa. 3. ed. Porto Alegre: Artmed, 2009.

GALLEGO, F. Social TV Analytics: nuevas métricas para una nueva forma de ver televisión. Index.comunicación, Madrid, n. 3, p. 13-39, 2013. Disponível em: <http://journals.sfu.ca/indexcomunicacion/index.php/indexcomunicacion/ article/view/ 49/56>. Acesso em: 7 mar. 2013.

HOGGART, R. As utilizações da cultura: aspectos da vida da classe trabalhadora, com especiais referências a publicações e divertimentos, v. 1. Lisboa: Presença, 1973.

JACKS, N. et al. Telenovela em múltiplas telas: da circulação ao consumo. In: LOPES, M. I. V. de (Org.). Ficção televisiva transmidiática no Brasil: plataformas, convergência, comunidades virtuais. Porto Alegre: Sulina, 2011. p. 297-338.

JACKS, N. et al. Passione e Avenida Brasil: produção crossmídia e recepção transmidiática? In: LOPES, M. I. V. de (Org.). Estratégias de transmidiação na ficção televisiva brasileira, v. 3. 1. ed. Porto Alegre: Sulina, 2013. p. 179-215.

JENKINS, H. Cultura da convergência. 2. ed. São Paulo: Aleph, 2009.

LIPOVETSKY, G. A terceira mulher: permanência e revolução do feminino. Lisboa: Instituto Piaget, 1997.

LOPES, M. I. V. de. Telenovela como recurso comunicativo. Matrizes, v. 3, n. 1, p. 21-47, ago./dez. 2009.

Ficção televisiva transmidiática no Brasil: plataformas, convergência, comunidades virtuais. Porto Alegre: Sulina, 2011.

LOPES, M. I. V. de; FREIRE, C. A dimensão epistemológica do monitoramento on-line: para um estudo crítico das técnicas de pesquisa na internet. In: XXI ENCONTRO DA COMPÓS, 2012, Juiz de Fora. Anais... Disponível em: <http://www. compos.org.br/data/biblioteca_1902.doc>. Acesso em: 27 abr. 2013.

LOPES, M. I. V. de et al. Transmediação, plataformas múltiplas, colaboratividade e criatividade na ficção televisiva brasileira. In: - (Orgs.). Ficção televisiva no Brasil: temas e perspectivas. São Paulo: Globo, 2009. p. 395-432. 
. Das ficções às conversações: a transmidiação do conteúdo ficcional na fan page da Globo. In: LOPES, M. I. V. de (Org.). Estratégias de transmidiação na ficção televisiva brasileira, v. 3. 1. ed. Porto Alegre: Sulina, 2013. p. 135-177.

MONTEIRO, D.; AZARITE, R. Monitoramento e métrica de mídias sociais: do estagiário ao CEO. São Paulo: DVS, 2012.

NASCIMENTO, C.; ALVES, I. A trama simbólica das piriguetes e putões: um estudo das representações de gênero nos pagodes baianos e na cultura. In: COSTA, A. A. A. (Org.). Estudos de gênero e interdisciplinaridade no contexto baiano. Salvador: EDUFBA; NEIM, 2011. p. 87-116.

NO BRASIL 43\% dos internautas assistem à tv enquanto navegam. IBOPE. 26 dez. 2012. Disponível em:<www.ibope.com.br/pt-br/relacionamento/imprensa/ releases/Paginas/No-Brasil-43-dos-internautas -assistem-a-TV-enquantonavegam.aspx>. Acesso em: 4 abr. 2013.

OIKAWA, E.; JOHN, V.; AVANCINI, D. De @berilopassione a \#MeServeVadia: Passione e Avenida Brasil no contexto de convergência midiática. Ciberlegenda, n. 27, p. 106-118, 2012. Disponível em: <http://www.uff.br/ciberlegenda/ojs/index. php/revista/article/viewFile/584/336>. Acesso em: 17 set. 2013.

OROZCO GÓMEZ, G. La condición comunicacional contemporánea. Desafíos latinoamericanos de la investigación de las interacciones en la sociedad red. In: JACKS, N. et al. (Orgs.). Análisis de recepción en América Latina: un recuento histórico con perspectivas al futuro. Quito: CIESPAL, 2011. p. 377-408.

OROZCO GÓMEZ, G.; GONZÁLEZ REYES, R. Una coartada metodológica: abordajes cualitativos en la investigación en comunicación, medios y audiencias. México: Produtora de Contenidos Culturales, 2011.

PÊCHEUX, M. Análise automática do discurso (AAD-69). In: GADET, F.; HAK, T. (Orgs.). Por uma análise automática do discurso: uma introdução à obra de Michel Pêcheux. 4. ed. Campinas: UNICAMP, 2010. p. 59-158.

SIFUENTES, L.; VILELA, M. D.; JEFFMAN, T. M. O dia em que a internet congelou: apropriações de Avenida Brasil nas mídias sociais. Sessões do Imaginário, Porto Alegre, v. 17, n. 27, p. 11-21, out. 2012. Disponível em: <http://revistaseletronicas. pucrs.br/ojs/index.php/famecos/article/view/12158>. Acesso em: 18 out. 2013.

SKEGGS, B. Formations of class and gender. London: Sage, 2002.

SOARES, T. Conveniências performáticas num show de brega no Recife: espaços sexualizados e desejos deslizantes de piriguetes e cafuçus. Logos, v. 19, n. 1, p. 55-67, 2012. Disponível em: <http://www.logos.uerj.br/PDFS/36/logos_36_ completa.pdf>. Acesso em: 18 abr. 2013. 